\title{
Communicative Language Teaching: Possible Alternative Approaches to CLT and Teaching Contexts
}

\author{
Wafaa Abdullah Alamri ${ }^{1}$ \\ ${ }^{1}$ English Language Institute, King AbdulAziz University, Jeddah, Saudi Arabia \\ Correspondence: Wafaa Abdullah Alamri, English Language Institute, King AbdulAziz University, Jeddah, \\ Saudi Arabia. E-mail: waalamri@kau.edu.sa
}

\author{
Received: June 9, 2018 Accepted: September 22, 2018 Online Published: September 25, 2018 \\ doi: 10.5539/elt.v11n10p132 URL: http://doi.org/10.5539/elt.v11n10p132
}

\begin{abstract}
There are various approaches of language teaching, in which communicative language teaching is the dominant approach worldwide. CLT approach allows language learners to express themselves and their views through collaborative activities undertaken during classes. This descriptive study has discussed CLT, offering both advantages and limitations. The CLT approach has led to major changes in such ways, in which language is taught and learnt. CLT aims to make "commnicative competence" the goal of language teaching and to develop procedures for teaching the four language skills, including listening, speaking, reading, and writing. It is well known that CLT approach allows language learners to express themselves and their views through collaborative activities, undertaken during classes. CLT, which is applied in schools, universities, colleges, and language institutes in most countries worldwide, stimulates learners' interests in learning by infusing the learning environment with new types of activities and materials that are both interactive and authentic. CLT is becoming a major language and its being used worldwide. The learners of the language are more focused towards learning the concepts. The emphasize is not towards understanding the language structures and lexical collocations. The main aim of the CLT is to make individuals competent in communication.
\end{abstract}

Keywords: communicative language teaching, English as a foreign language, context approach

\section{Introduction}

A wide range of approaches and methods have been developed worldwide for language teaching over the years. Savignon (1997) defined communicative competence as the expression, interpretation, and negotiation of meaning; and CLT encourages language learners to acquire language knowledge as well as the ability to use the language. Unlike the traditional teaching approaches, CLT is rooted in a shift "from emphasis on form to emphasis on communication" (Cook, 2003, p. 36). It also involves classroom activities that engage learners with language use in a more meaningful and authentic manner. CLT thereby supports the teaching and learning processes by enhancing their power and vitality.

CLT enables language learners to communicate in target language. That is, learning takes place "through the process of struggling to communicate" (Finocchiaro \& Brumfitqtd, in Brown, 2007, p. 49). Teaching methods and approaches vary depending on teaching-related aspects and factors; such as motivation, classroom interaction, and classroom setting. These approaches include grammar translationaudio-lingual, and communicative language teaching (CLT) approaches. It is the researcher's view; however, that whenever a teaching or learning approach or method focuses on a specific aspect at the expense of others, an area of imperfection results. The study critically assessed certain issues related to CLT and examined the implications of method for teaching and learning. The study has also provided opinions and evidence, while referring to the arguments and ideas presented in the CLT literature. The teacher's role is to facilitate, advice, and guide the learners in the classroom; while the language learners are communicators, who negotiate the meanings that are unclear. CLT concentrates on one strong aspect of teaching and considers it as the source of learning-communication.

\section{Methodology}

A literature search has been carried out by exploring scholarly platforms such as Google Scholar, to retrieve quality studies regarding Communicative Language Teaching and alternative approaches to CLT and Teaching 
Contexts. Initially, 450 studies were searched, out of which 7 relevant studies have been selected. The selection was based on the topic and the context of the research. While assessing the research studies, the core focus of the studies was evaluated along with the objective of the research studies. In addition, the methodology was examined and the results of those studies were evaluated to retrieve the relevant outcomes.

\section{Related Work}

Despite its useful function in the profession, some scholars have argued that CLT approach has a negative effect on teaching, and they have consequently called for a paradigm shift away from the approach. CLT has always neglected as one key aspect of language, the context in which it takes place (Al-Asmari, 2015; Bax, 2003). CLT provides teachers with only one message: "communicative approach is the way to do it, no matter where you are, no matter what the context" (Bax, 2003, p. 282).

Tomlinson (2001) argued that CLT dominates material production, which means that course-books are not valuable in teaching and learning processes, and it is precisely the situation that is observed in most schools and universities today. Textbooks are full of collaborative activities, which are unrelated to the context of the lesson. Moreover, teachers are required to introduce more activities to the class for communicative purposes without regard for the context of the lesson or the learners' needs. Moreover, reflecting learners' cultures and needs in the classrooms, as well as focusing on other aspects of teachings beneficial for learning outcomes. Sometimes, real communication in the classroom is not required for all class activities. Rather, the context itself should be the center of learning and teaching.

Berns (2013) has argued that communicative language teaching plays a major role in the development of certain skill sets among learners. Communicative language teaching allows the learner to know about social and cultural considerations. Richards and Schmidt (2014) have mentioned that communicative language learning is also significant for the learners to participate in the real world in an effective way. Candlin (2016) further indicated that sociolinguistics and communicative language teaching are highly correlated, and it has presented relatively excellent outcomes in terms of learning.

The study agreed with the view, especially in light of his description of the obsession with CLT and its priorities. This kind of obsession leads to a neglect for most aspects of the language learning context.

Ellis (1996) recognized the mediating role of teacher, which is a useful tool in such process. Ellis (1996) also examined the notion of problems in implementing CLT and connected it to the teacher's role. Similarly, using authentic materials from the learners' cultural context; such as posters, newspapers, and devices, may help in implementing the CLT approach in different cultural contexts. Another study indicated difficulties in the implementation of the CLT Approach due to the issues faced but the teachers. Ozsevik (2010) concluded that teachers are overburdened and underpaid, and thus do not focus their attention in implementing and adapting the CLT Approach in teaching. Similarly, a study conducted by Walia (2012) also revealed that not only Teachers were reluctant to adopt the CLT method, but also Students were hesitant to participate in CLT activities. Additionally, time constraints and the costs involved also discouraged the use of CLT practices in classrooms in Rajasthan (Walia, 2012). In a study conducted by Chowdhury (2012), it was revealed that socio-cultural influences make it difficult to implement the CLT approach in higher secondary schools in Bangladesh.

\section{Textbooks, Cultures and Learning Situations}

Context should be as important as communication in teaching and learning processes. When the English as a foreign language (EFL) teacher views the context, including textbooks, cultures, and learning situations, as being as important as classroom interaction, the overall teaching and learning objectives are achieved. Context should be at the heart of the lesson, because it is the source of interaction, activities, tasks, assessments, and knowledge. According to Bax (2003), it is the learning context, which should be the first priority, as focusing on context "will include an understanding of individual students and their learning needs, wants, and strategies ... as well as course books, local conditions, [and] the classroom culture" (p. 285). The teacher should use the coursebook to create collaborative activities, which help learners to improve their language skills, gain more knowledge, and solve language problems. According to Holliday, "to be appropriate, a methodology must be sensitive to the prevailing cultures surrounding any given classroom" (1994, p. 161).

It is usually noticed that the English language learners, who are at the advanced level are, for the most part, fluent; they have the ability to communicate and interact with people in English. However, they commit crucial errors in regard to the language form, which means that they need more practice as it relates to their grammar skills (Chang, 2011). This is because the learners' errors of form are tolerated, by the teachers, during their interaction or activities, as they use the second language to express themselves without any regard for the 
language form. Therefore, communication is not sufficient for learning a language. Teachers need to focus on grammar rules in class and to correct learners' form-related errors, especially the crucial ones related to interpretation, expression, and negotiation of meaning. CLT's communication purposes are focused on speaking activities in which the teachers emphasize language meaning while ignoring the language form. Thus, fluency gains much more significance.

Authentic materials refer to texts, photographs, video selections, and other teaching resources that are not specially prepared for pedagogical purposes (Richards, 2001). Teachers in communicative language classrooms need to use more authentic materials, which help in the language and teaching processes. Textbooks are full of activities, which can be applied to the learners' cultures. For example, some textbooks editions are replete with activities and exercises, which can be connected to authentic materials, such as letters, emails, and celebrations. In second language learning environments, learners work cooperatively on a language learning task by achieving the goal through the communicative use of the target language. Teachers, therefore, need to connect the class activities to the learners' daily lives by referring to the content within the textbooks.

In addition to context, language structure is highlighted as one of the misconceptions of CLT. Undeniably, CLT as a teaching approach is widely accepted by the teaching profession, and its two guiding principles, developing learners' communicative competence and communication, are the means to accomplish language learning. In regard to the traditional methods, "there is no oral or pronunciation work, since it is the written language which is taught, and 'mental discipline' is stressed rather than any ability to actually use the language" (White, 1988, p. 65). Contrastingly, CLT deals more with interaction and communication while paying less attention to language form; this is perhaps because "the user's attention is focused on meaning rather than linguistic structure" (Nunan, 1989, p. 10). In fact, language form is as crucial as meaning and that changing the structure of a language would definitely change its meaning.

\subsection{Communicative Language}

Littlewood (1985) pointed out that "communicative language use is only possible ... by virtue of the grammatical system and its creative potential" (p. 40). That is to say, grammar is not a secondary element of language learning; rather, it is a primary aspect, and learning should be taught because of its importance to meaning. Similarly, Widdowson (1978) argued that the "proper understanding of the concept of communicative competence would have revealed that it gives no endorsement for the neglect of grammar" (p. 40).

Target language forms should be taught in meaningful contexts to ensure that they remain memorable. Littlewood (1981) and Mitchell (1994) stated that CLT gives us fluency, purposeful communicative activities, and student-student interaction. Lightbown (1998) mentioned one reason why teachers may not be expected to concentrate on language form: Teachers believe that drawing students' attention to grammar while they are engaging in meaning-making may have harmful effects. However, the teacher's ability to encourage his or her students during grammar exercises can be both meaningful and communicative.

CLT is a successful approach that creates fluent language speakers and communicators; however, they are mostly unskilled with regard to language writing. In Saudi Arabia, since the teaching and curriculum plans have been changed from the traditional to the CLT approach, it has been found that language learners in secondary school are able to communicate and interact in English; however, they make crucial mistakes when writing. Their textbooks are full of collaborative activities which provide them with more opportunities to use the language rather than forming sentences. The language teachers also tend to teach the social language that learners would use to communicate with others, and this is done using well-formed structures for talking to visitors from different countries, booking a hotel, and getting around in a foreign country, for example (Mahboob \& Elyas, 2014). Thus, "grammar is not an optional add-on to communication. It lies at the heart of communication" (Lock, 1996, p. 267).

\section{Discussion}

Another problem with the CLT approach relates to the roles of teachers and learners. Unlike the traditional approaches, CLT changes the role and nature of the classroom, making it learner centered. The adoption of CLT principles marked the beginning of a paradigm shift that led to numerous changes in how second language teaching is conducted and conceived (Richards, 2001). Language is learned through learner-learner interaction, and the teacher's role is to facilitate and guide the learning process. Dornyei (2013) supported this outcome, and indicated that there are around 10 communication language learning strategies in the 21st century. Fan (2016) further highlighted this aspect that learner-learner interaction is significantly helpful in the communicative language teaching; thus, CLT approach is directly associated with the role of teachers and learners. 
Littlewood (1981) described the teacher's role in communicative activities as follows: "[he or she] will let learning take place through independent activities" (p. 92). The language teacher consequently provides the language learners with collaborative activities only. The classroom atmosphere was learner-centered in that the teacher merely provided instructed activities and monitored the class. I have observed one of these classes. It is beneficial to ensure that the students are active and cooperative. However, in my view, if these cooperative activities are not related to the context of the lesson being delivered by the teacher, and there are no detailed references to the lesson's objectives, the students' hard work will have no meaning, with the exception of the area of communication. Thus, when designing activities, the teacher's role is not only to facilitate or guide students. Harmer (1982) suggested that students are thrown into a communicative situation "as a prelude to any instruction: all subsequent teaching is based on whether they sink or swim" (p. 164). As a language instructor, I see this is a negative effect of CLT; the learners need more from teachers who correct errors, justify, instruct, provide feedback, evaluate, and interact effectively with them both inside and outside of the classroom setting. Furthermore, exams are designed to test only linguistic rather than communicative competence. The following point is one misconception of CLT: Learners' collaborative communicative abilities cannot be measured in exams, as CLT classrooms emphasize the communicative listening and speaking skills. Accordingly, the CLT approach does not provide a useful solution to this problem.

Table 1. Systematic review analysis

\begin{tabular}{|c|c|c|c|c|}
\hline $\begin{array}{ll}\text { Authors } & \text { Name } \\
\text { and Year } & \end{array}$ & Title of the Article & Methodology & Results & Conclusion \\
\hline Al Asmari 2015 & $\begin{array}{l}\text { Communicative } \\
\text { language teaching } \\
\text { in EFL university } \\
\text { context: Challenges } \\
\text { for teachers. }\end{array}$ & Quantitative Study & $\begin{array}{l}\text { The findings } \\
\text { reveal that there is } \\
\text { lack of motivation } \\
\text { among students } \\
\text { and lack of } \\
\text { adequate CLT } \\
\text { Training }\end{array}$ & $\begin{array}{l}\text { Teachers have to face } \\
\text { many obstacles with } \\
\text { regard to the students, } \\
\text { CLT and the education } \\
\text { system }\end{array}$ \\
\hline Chang 2011 & $\begin{array}{lr}\text { A contrastive study } \\
\text { of } \\
\text { translation } \\
\text { and communicative } \\
\text { approach } \\
\text { teaching } & \text { English } \\
\text { grammar } & \end{array}$ & Comparative study & $\begin{array}{l}\text { The findings } \\
\text { revealed that the } \\
\text { grammar } \\
\text { translation method } \\
\text { was better than } \\
\text { the } \\
\text { communicative } \\
\text { approach in } \\
\text { teaching grammar. }\end{array}$ & $\begin{array}{l}\text { It was concluded that the } \\
\text { grammar translation } \\
\text { method provides } \\
\text { accuracy, while the } \\
\text { communicative } \\
\text { approach provides } \\
\text { fluency when learning } \\
\text { grammar. It is best to } \\
\text { combine both methods } \\
\text { when learning English. }\end{array}$ \\
\hline $\begin{array}{l}\text { Ahmar Mahboob } \\
\text { and Tariq Elyas } \\
2014\end{array}$ & $\begin{array}{l}\text { English in the } \\
\text { Kingdom of Saudi } \\
\text { Arabia }\end{array}$ & Quantitative Study & $\begin{array}{l}\text { The results } \\
\text { revealed that } \\
\text { Saudi English has } \\
\text { local } \\
\text { characteristics and } \\
\text { reflects the local } \\
\text { culture and norms. }\end{array}$ & $\begin{array}{l}\text { It was concluded that } \\
\text { Saudi English is } \\
\text { influenced by the local } \\
\text { behaviors, beliefs and } \\
\text { values and is gaining a } \\
\text { new identity of its own. }\end{array}$ \\
\hline Fan 2016 & $\begin{array}{l}\text { A Brief } \\
\text { Introduction to } \\
\text { Communicative } \\
\text { Language Teaching }\end{array}$ & Qualitative Study & $\begin{array}{l}\text { The findings } \\
\text { indicate the } \\
\text { importance of } \\
\text { student to student } \\
\text { communication } \\
\text { when learning a } \\
\text { language. }\end{array}$ & $\begin{array}{l}\text { The conclusion states } \\
\text { that learner-to -learner } \\
\text { communication assist in } \\
\text { the comprehension of a } \\
\text { new language }\end{array}$ \\
\hline Ozsevik 2010 & $\begin{array}{l}\text { The use of } \\
\text { Communicative }\end{array}$ & $\begin{array}{l}\text { Mixed Method } \\
\text { research design }\end{array}$ & $\begin{array}{lr}\text { The } & \text { findings } \\
\text { revealed } & \text { that }\end{array}$ & $\begin{array}{l}\text { It was concluded that the } \\
\text { chief reason for teachers }\end{array}$ \\
\hline
\end{tabular}




\begin{tabular}{|c|c|c|c|c|}
\hline & $\begin{array}{ll}\text { Language } & \\
\text { Teaching: Turkish } \\
\text { EFL } \\
\text { perceived } \\
\text { difficulties } \\
\text { implementing } \\
\text { in Turkey }\end{array}$ & & $\begin{array}{l}\text { teachers find it } \\
\text { difficult to } \\
\text { implement the } \\
\text { CLT approach due } \\
\text { to being } \\
\text { overburdened and } \\
\text { underpaid. }\end{array}$ & $\begin{array}{l}\text { demotivation to adapt } \\
\text { the CLT approach was } \\
\text { overwork and less pay. }\end{array}$ \\
\hline Walia 2012 & $\begin{array}{l}\text { Traditional } \\
\text { teaching methods } \\
\text { vs. CLT: A study }\end{array}$ & Quantitative Study & $\begin{array}{l}\text { The findings show } \\
\text { that teachers are } \\
\text { reluctant to apply } \\
\text { the CLT method } \\
\text { as they are } \\
\text { comfortable with } \\
\text { the traditional } \\
\text { teaching methods. }\end{array}$ & $\begin{array}{l}\text { It was concluded that } \\
\text { teachers did not want to } \\
\text { adapt CLT teaching } \\
\text { method in their } \\
\text { classrooms. This found } \\
\text { it overwhelming and } \\
\text { resigned to traditional } \\
\text { language teaching } \\
\text { approaches. }\end{array}$ \\
\hline Chowdhury 2012 & $\begin{array}{l}\text { Communicative } \\
\text { Language Teaching } \\
\text { approach at higher } \\
\text { secondary level in } \\
\text { Bangladesh- } \\
\text { Teachers } \\
\text { perceptions and } \\
\text { classroom practice }\end{array}$ & Quantitative study & $\begin{array}{l}\text { The study } \\
\text { revealed that } \\
\text { socio-cultural } \\
\text { influences make it } \\
\text { difficult to } \\
\text { implement the } \\
\text { CLT approach in } \\
\text { higher secondary } \\
\text { schools in } \\
\text { Bangladesh. }\end{array}$ & $\begin{array}{l}\text { It was concluded that the } \\
\text { adaptation of the CLT } \\
\text { approach must include } \\
\text { the socio-cultural } \\
\text { realities in countries } \\
\text { teaching EFL. }\end{array}$ \\
\hline
\end{tabular}

\section{Conclusion}

CLT is the dominant language teaching approach worldwide. It is believed that this approach has strengthened teaching and learning processes because of its focus on the power of communication. Communication is considered as the source of learning, and is the medium of teaching. Nevertheless, the emphasis on one specific aspect as the main tool of learning highlights an imperfection in the CLT approach. CLT leads to the erroneous belief that if the learners are communicating, that they must be learning, and such a belief can be harmful. Many teachers assume that all they need to do is set communicative activities in the classroom to enable learning to take place. The result; however, is that the learner's attention is focused on meaning rather than linguistic structure. Moreover, as previously mentioned, the learning and teaching contexts are ignored. As Bax (2003) argued the implication is that the context in which we teach is marginalized, relegated, and sidelined.

It has been evaluated that a new alternative is required for CLT. However, CLT approach could be improved by considering the whole context. In addition, language structure and assessment should receive more attention. The new context approach presented by Bax (2003), aimed to find solutions to CLT's shortcomings; however, it is expected to create new problems. It underscores the fact that no perfect approach to learning or teaching exists; rather, different teaching contexts require the use of different approaches (Prabhu, 1990). Although there is no perfect approach to, or method of, language teaching or learning, what we need as teachers and students is for a carefully considered approach to be applied in regard to communication, learners' needs and motivation, context, cultures, and grammar. The EFL learner "has to learn rules of communication as well as rules of grammar" (Wilkins, 1976, p. 11). Fotos (2003) also justifiably claimed that instead of favoring one method over the other, grammar teaching and communicative activities should be combined to achieve teaching goals. Therefore, a mix of grammar, context, and communicative language teaching approaches can be a useful method for achieving the desired level of language learning or teaching. Widdowson (1978) claimed that "what the learners need to know how to do is to compose in the act of writing, comprehend in the act of reading, and to learn techniques of reading by writing and techniques of writing by reading" (p. 144).

\section{References}

Al Asmari, A. A. (2015). Communicative language teaching in EFL university context: Challenges for teachers. 
Journal of Language Teaching and Research, 6(5), 976-984. https://doi.org/10.17507/j1tr.0605.09

Bax, S. (2003). The end of CLT: A context approach to language teaching. ELT journal, 57(3), 278-287. https://doi.org/10.1093/elt/57.3.278

Berns, M. (2013). Contexts of competence: Social and cultural considerations in communicative language teaching. Springer Science \& Business Media.

Brown, H. D. (2007). Teaching by Principles. An Interactive Approach to Language Pedagogy. New Jersey: Prentice Hall Regents.

Candlin, C. N. (2016). Sociolinguistics and communicative language teaching. ITL-International Journal of Applied Linguistics, 16(1), 37-44.

Chang, S. C. (2011). A contrastive study of grammar translation method and communicative approach in teaching English grammar. English Language Teaching, 4(2), 13. https://doi.org/10.5539/elt.v4n2p13

Chowdhury, K. B. (2012). Communicative Language Teaching Approach at Higher Secondary Level in Bangladesh-Teachers' Perceptions and Classroom Practice. Language in India, 12(2).

Cook, G. (2003). Applied linguistics. Oxford University Press.

Dornyei, Z. (2013). Communicative language teaching in the twenty-first century: The principled communicative approach. In J. Arnold, \& T. Murphy, Meaningful Action (Eds.), (pp. 161-171).

Ellis, G. (1996). How culturally appropriate is the communicative approach?. ELT journal, 50(3), 213-218. https://doi.org/10.1093/elt/50.3.213

Fan, J. I. N. (2016). A Brief Introduction to Communicative Language Teaching. Journal of Language Teaching and Research, 2(2), 428-431. https://doi.org/10.4304/j1tr.2.2.428-431

Fotos, S. (2003). Traditional and grammar translation methods for second language teaching. In E. Hinkel (Ed.), Handbook of research in second language teaching and learning (pp. 653-668). Mahvah, NJ: Lawrence Erlbaum Associates.

Harmer, J. (1982). What is communicative? ELT Journal, 363, 164-168. https://doi.org/10.1093/elt/36.3.164

Holliday, A. (1994). Appropriate methodology and social context. Cambridge: Cambridge University Press.

Lightbown, P. M. (1998). The importance of timing in focus on form. In C. Doughty, \& J. Williams (Eds.), Focus on form in classroom second language acquisition (pp. 177-196). Cambridge: Cambridge University Press.

Littlewood, W. (1981). Communicative language teaching. Cambridge: Cambridge University Press.

Lock, G. (1996). Functional English grammar: An introduction for second language teachers. Cambridge: Cambridge University Press.

Mahboob, A., \& Elyas, T. (2014). English in the kingdom of Saudi Arabia. World Englishes, 33(1), 128-142. https://doi.org/10.1111/weng.12073

Mitchell, R. (1994). The communicative approach to language teaching. In S. Ann (Ed.). Teaching Modern Languages. New York: Routledge.

Nunan, D. (1989). Designing tasks for the communicative classroom. Cambridge: Cambridge University Press

Ozsevik, Z. (2010). The use of communicative language teaching (CLT): Turkish EFL teachers' perceived difficulties in implementing CLT in Turkey.

Prabhu, N. S. (1990). There is no best method-why?. Tesol Quarterly, 24(2), 161-176. https://doi.org/10.2307/3586897

Richards, J. C., \& Rodgers, T. S. (2001). Approaches and methods in language teaching (2nd ed). Cambridge: Cambridge University Press.

Richards, J. C., \& Schmidt, R. W. (2014). Language and communication. Routledge. https://doi.org/10.1017/CBO9780511667305

Savignon, S. J. (1997). Communicative competence, theory and classroom practice: Texts and contexts in second language learning (2nd ed.) New York: McGraw-Hill.

Tomlinson, B. (2001). Humanising the Coursebook. Humanising Language Teaching, 3(5).

Walia, D. N. (2012). Traditional teaching methods vs. CLT: A study. Frontiers of language and teaching, 3(1), 125-131. 
White, R. V. (1988). The ELT Curriculum. Oxford: Blackwell Publishers Ltd.

Widdowson, H. G. (1978). Teaching language as communication. Oxford: Oxford University Press

Wilkins, D. (1976). Notional syllabuses. Oxford: Oxford University Press.

\section{Copyrights}

Copyright for this article is retained by the author(s), with first publication rights granted to the journal.

This is an open-access article distributed under the terms and conditions of the Creative Commons Attribution license (http://creativecommons.org/licenses/by/4.0/). 